\title{
The Effect of Marigold Leaves and Doxorubicin Toward Cell Cycle and Apoptosis of T47D Cells
}

\author{
Anis Fauzia, Umi Any Tiyas Wati, Cahyaning Gita Rizkita, Eka Wahyuni Nurul \\ Qori'ah, Ibrahim Arifin*
}

Pharmacy, Faculty of Pharmacy, Wahid Hasyim University, Semarang, Indonesia

\begin{abstract}
Doxorubicin is a commonly used chemotherapeutic agent in patients with breast cancer. The risk of side effect using of doxorubicin such as cardiomyopathy and congestive heart failure which can lead to death. One of the approach to overcome overloaded use of doxorubicin is the combined use with a chemopreventive agent (cochemotherapy), including the leaf extract of marigolds (Cosmos caudatus Kunth.). This research aims to reviewing the effect of the methanol extract of leaves of marigolds on the cytotoxic activity of doxorubicin in modulating cell cycle and apoptosis of breast cancer cells T47D. Determination of the cytotoxic activity of methanol extract of leaves of marigolds and doxorubicin as well as a combination of both conducted by MTT assay. modulation surveillance of cell cycle and apoptosis induction is done by using flowcytometry and analyzed by FACS Calibur program. Cytotoxicity assay single treatment of the methanol extract of leaves of marigolds produce use values of $I C_{50} 504.840 \mu \mathrm{g} / \mathrm{mL}$, whereas $I_{50}$ values doxorubicin is $141.055 \mathrm{nM}$. The synergistic effect was shown a combination of methanol extract leaves marigolds and doxorubicin at concentrations of $84.17 \mu \mathrm{g} / \mathrm{mL}-23.5 \mathrm{nM} ; 84.17 \mu \mathrm{g} / \mathrm{mL}-47 \mathrm{nM} ; 126.25 \mu \mathrm{g} / \mathrm{mL}$ $-23.5 \mathrm{nM} ; 252.5 \mu \mathrm{g} / \mathrm{mL}-35.25 \mathrm{nM}$ and $252.5 \mu \mathrm{g} / \mathrm{mL}-7 \mathrm{IMM}$ with a combination index value (Cl) consecutively of $0.5 ; 0.6 ; 0.6 ; 0.6$ and 0.6 . Observations modulation of cell cycle and apoptosis induction combination of methanol extract leaves marigolds and doxorubicin at concentrations of $84.17 \mu \mathrm{g} / \mathrm{mL}-23.5 \mathrm{nM}$, said that a combination of the methanol extract of leaves of marigolds and doxorubicin to inhibit the proliferation of cells in G2/M phase and able to induce apoptosis of breast cancer cells T47D.
\end{abstract}

Keywords: methanol extract of leaves of marigolds, doxorubicin, flowcytometry, cell cycle, apoptosis.

\section{INTRODUCTION}

Breast cancer is type of cancer that common suffered by women in the world. $15 \%$ of them end up with death. Currently Indonesia occupy the first position in Asia as a country with the highest number of new breast cancer cases, that is 25,208 cases (IARC, 2013).

The main priority of breast cancer therapy was conducted using agent chemotherapy. One of the agents chemotherapy known as an effective cancer therapy is doxorubicin (Drummond, 2007). But the use of doxorubicin in clinical restricted because of side effects cardiomyopathy and congestive heart failure that can cause death (Singal, et al., 2001).

To overcome the side effects of the doxorubicin, one strategy developed is by combining doxorubicin and natural material that has cytotoxic effect, one of it is kenikir leaves (Cosmos caudatus Kunth.), Fita, et al., 2015 prove that the combination of methanol extract of marigolds leaves extract (MLE) and doxorubicin showed cytotoxic effect that strong synergistic. In this study, we observed the ability of a combination of MLE and doxorubicin in modulate cell cycle and improve induction of cell apoptosis on T47D breast cancer cells. The molecular search of the mechanism is going to be beneficial as the basic development of kenikir leaves as a cochemotherapy agnet that can be minimize the therapeutic dose of doxorubicin so that it will minimize the side effects of the use of doxorubicin, and also to convince the health practitioners to use natural material in the practice of treating breast cancer.

$\overline{\text { *Corresponding author e-mail : ibrahim_arifin.0919@yahoo.co.id }}$ 


\section{MATERIALS AND METHODS}

\section{Study Period}

This research has been held in March 2016 until July 2016, including observation, collection raw materials, making methanol extract of marigolds leaves in the laboratory phytochemical, Wahid Hasyim University. Cytotoxic assay dan observation of cell cycle modulation and apoptosis in the laboratory molecular biology BP2TOOT, Tawangmangu, and data analysis until the preparation of report.

\section{Material and Instruments}

Extraction materials : Marigold leaves (Cosmos caudatus Kunth.), methanol.

Cytotoxic assay, cell cycle and apoptosis materials : methanol extract of marigold leaves, DMSO, doxorubicin, T47D breast cancer cell lines, DMEM media, grower media containing FBS $10 \%$ and penicillinstreptomycin 1\%, PBS, MTT reagent, Stopper reagent in the form of SDS $10 \%$ in HCL 0.01 $\mathrm{N}$, Flowcytometry reagent (Propidium Iodide (PI), RNAse and $0.1 \%(\mathrm{v} / \mathrm{v})$ Triton-X 100 in PBS, alcohol 70\%, annexin V-FLOUS Apoptosis Detection Kit, Tripsin- EDTA $0.25 \%$.

Extraction instruments: soxhletation instrumen, rotary evaporator, beakerglass, measuring glass, funnel,boiling stone, heater.

Cytotoxic assay, cell cycle and apoptosis observation instruments: vortex, $\mathrm{CO}_{2} 5 \%$ incubator, treated tissue culture dish diameter $10 \mathrm{~cm}$, inverted microscop, laminar air flow cabinet, micropipet, yellow-tip, blue-tip, reaction tube, conical tube, 96 well-plate, 6 well-plate, sentrifuge tube, sentrifuge, object glass, flowcytometer, digital camera, ELISA reader.

\section{Plant Determination}

Plant determination was done in Ecology dan Biosystematic Laboratory, Biology Departement, Faculty of Mathematics and Sciences, Diponegoro University, Semarang.

\section{Extraction}

Marigold leaves washed with water and dried in an oven with the temperature maximum $400^{\circ} \mathrm{c}$ until the water levels $<10 \%$ (Depkes RI, 1979). Simplisia mashed and sifted with B30 sieve. Simplisia extracted with methanol used the soxhletation method.The obtained liquid extract then volatilized with rotary evaporators to obtained the viscous consistency.

\section{Cytotoxic Assay}

Test Solution of MLE dissolved in DMSO and made the series a concentration of $1000,850,700,550,400,250$, and $100 \mu \mathrm{g} / \mathrm{mL}$, whereas doxorubicin made the series a concentration of $250,200,150,100,50,25$, 12.5 , and $2.5 \mathrm{nM}$, T47D cells in a nitrogen tank subcultured in a culture medium until ready to test. A number of $8 \times 10^{3}$ cells/well distributed in wells on a 96 well plate and incubated in 5\% $\mathrm{CO}_{2}$ incubator at $37^{\circ} \mathrm{C}$ for overnight. Step in single testing or in combination, namely the test solution was added to the wells and incubated for 24 hours. Media is removed, then each of the wells are washed with PBS, then added to the culture medium of $100 \mathrm{~mL}$ and $10 \mathrm{~mL}$ MTT with a concentration of $5 \mathrm{mg} / \mathrm{mL}$. Cells were incubated for 2-4 hours to form formazan. MTT reaction was stopped by the stopper reagent in the form of $10 \%$ SDS in $0.01 \mathrm{~N} \mathrm{HCl}$ and incubated overnight at room temperature in a dark place. Uptake is read by ELISA reader at a wavelength of $595 \mathrm{~nm}$ (Mossman, 1983).

\section{Observation of Cell Cycle using Flowcytometry}

A number of $5 \times 10^{5}$ cells/well transferred into a 6-well plate and incubated in $5 \% \mathrm{CO}^{2}$ incubator at $37^{\circ} \mathrm{C}$ for 24 hours. Test solution is added to the wells and incubated for 24 hours. The cell media transferred to conical, $500 \mathrm{~mL}$ of PBS was added to the wells and transferred in the same conical. Cells were harvested by adding $200 \mathrm{~mL}$ of $0.25 \%$ trypsin-EDTA and incubated 3 minutes, added $1 \mathrm{~mL}$ of culture medium/well and resuspended. The harvested cells are transferred into the same conical and pitting rinsed with PBS and then transferred to the same conical. Centrifuged by $600 \mathrm{rpm}$ for 5 minutes and the supernatant was discarded. The precipitated cells were washed with cold PBS $500 \mathrm{~mL}$ and centrifuged by $600 \mathrm{rpm}$ for 5 minutes and then PBS discarded, added $500 \mathrm{~mL}$ of $70 \%$ alcohol and stored conical at a temperature of $37^{\circ} \mathrm{C}$ for 30 minutes and then centrifuged by $600 \mathrm{rpm}$ for 5 minutes and the alcohol is removed, add $500 \mu \mathrm{L}$ PBS and centrifuged by $2000 \mathrm{rpm}$ for 3 minutes. Flowcytometry reagent is added and allowed to stand 30 minutes in conical wrapped in aluminum foil. The cell suspension is transferred to flowcyto-tube and analyzed by 
FACS Calibur flowcytometer program to determine the profile of the cell cycle (Ayers, et al., 2011).

\section{Observation of Apoptosis using Flowcytometry}

A number of $5 \times 10^{5}$ cells/well transferred into a 6-well plate, incubated in a $5 \% \mathrm{CO}_{2}$ incubator at $37^{\circ} \mathrm{C}$ for overnight. Test solution is added to the wells and incubated for 24 hours. Conical transferred to the cell media and the wells are washed with $500 \mathrm{~mL}$ of PBS, then transferred to the same conical and harvesting with the addition of $0.25 \%$ trypsin-EDTA as much as $150 \mathrm{~mL} /$ well and incubated 3 minutes. Media culture is added $1000 \mathrm{~mL} /$ well and cells resuspended. Cells centrifuged by $600 \mathrm{rpm}$ for 5 minutes, the media removed. The cell sediment was dissolved in buffer kit annexin VFLOUS. The cell suspension was homogenized and incubated for $15 \mathrm{~min}$ at room temperature in conical wrapped in aluminum foil. Cells are then transferred to flowcyto-tube and analyzed (Gattenlohner, et al., 2009).

\section{Analysis of Cytotoxicity Assay Data}

Data absorbance or OD (Optical Dencity) of ELISA reader is converted to percent of cell viability using the following formula:

$\%$ Cell viability $=\frac{O D \text { treatment cells }-O D \text { media control }}{O D \text { cell control }-O D \text { media control }} \times 100 \%$

The results of calculations were analyzed using Microsoft Excel 2007 to obtain single treatment $\mathrm{IC}_{50}$ of MLE and doxorubicin. $\mathrm{IC}_{50}$ obtained from a single treatment is used to determine the concentration of the MLE combination and doxorubicin. Potential cytotoxic doxorubicin MLE combination determined by calculating the Combination Index using the formula (Reynolds and Maurer, 2005):

$$
C I=(D) 1 /(D x) 1+(D) 2 /(D x) 2
$$

The concentration of each test compound is used to test the combination stated in $D_{l}$ and $D_{2}$, whereas the concentration of a single compound derived from the interpolated percent cell viability caused by combination treatment $(\mathrm{X})$ in a single regression equation expressed in $D_{X 1}$ and $D_{X 2}$.

\section{Analysis of Cell Cycle Observation Data}

Data were analyzed by flowcytometry flowing program to see the distribution of the percentage of cells in G1 phase, S and G2/M. The inhibition of the cell cycle can be determined by comparing the treatment effect of the test solution with control cells.

\section{Analysis of Apoptosis Observation Data}

Flowcytometry data showed the percentage of cells contained in four quadrants, namely LL (lower left), LR (lower right), UL (upper left), and UR (upper right). LL quadrant showed the percentage of living cells, LR quadrant showed the percentage of cells undergoing early apoptosis, UL quadrant showed percent cell necrosis, UR quadrant showed the percentage of cells undergoing late apoptosis. Induction of apoptosis known to compare the effects of single compounds and combination treatment with control cells.

\section{RESULTS AND DISCUSSION}

The single cytotoxicity assay give the MLE $\mathrm{IC}_{50}$ values of $504.840 \mathrm{~g} / \mathrm{mL}$. It was less compared to research of Fita, et al., 2015 which provide $\mathrm{IC}_{50}$ of $778.05 \mu \mathrm{g} / \mathrm{mL}$ (Fita, et al., 2015), whereas doxorubicin cytotoxicity give $\mathrm{IC}_{50}$ value of $141.055 \mathrm{nM}$. Cytotoxicity profile of MLE which shows its ability in lowering T47D cells viability is presented in Fig. 1, while the morphology of breast cancer cells after treatment with doxorubicin and MLE is shown in Fig. 2.

Cytotoxicity combination assay was conducted to know the effectivy of the combination MLE and doxorubicin in inhibiting the growth of T47D cells. In the combination assay, the concentration of MLE and doxorubicin was lowered to under its $\mathrm{IC}_{50}$ respectively so can suppress the side effects of doxorubicin. The results show the Combination Index of MLE and doxorubicin as shown in Table 1. 


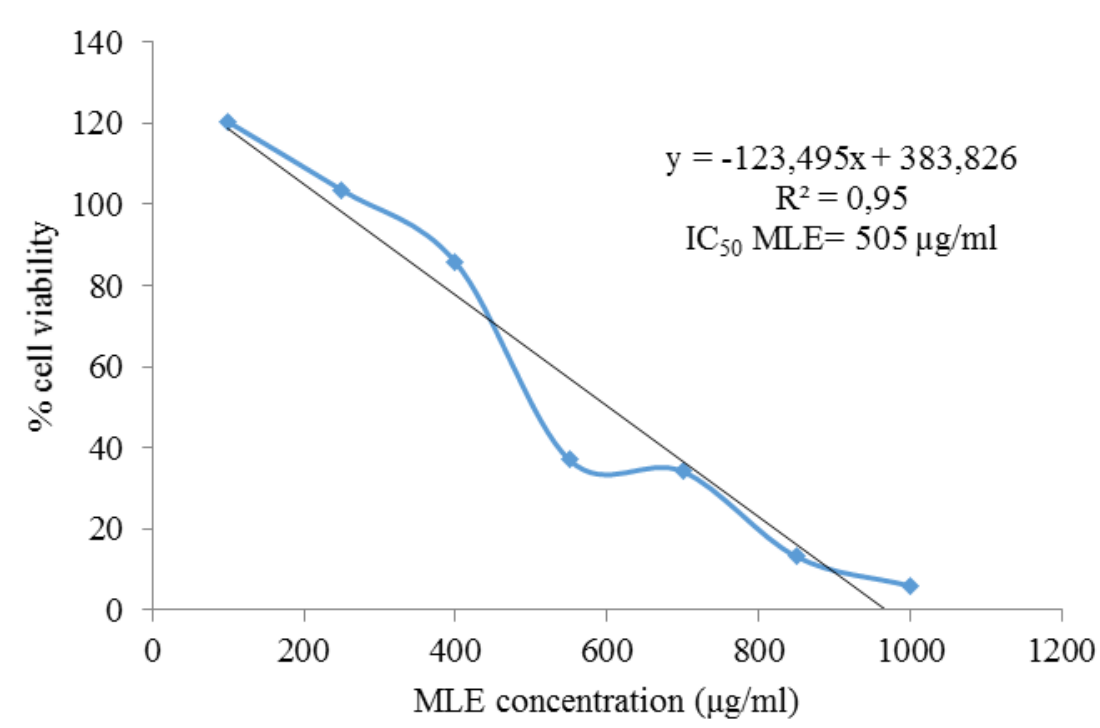

Figure I. The ability of MLE to decrease the viability T47D cell. Methanol extract kenikir leaves inhibits the growth of T47D breast cancer cell gives IC 50 value of $504.840 \mu \mathrm{g} / \mathrm{mL}$.

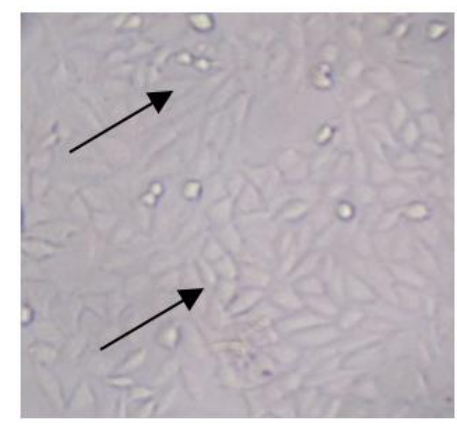

(A)

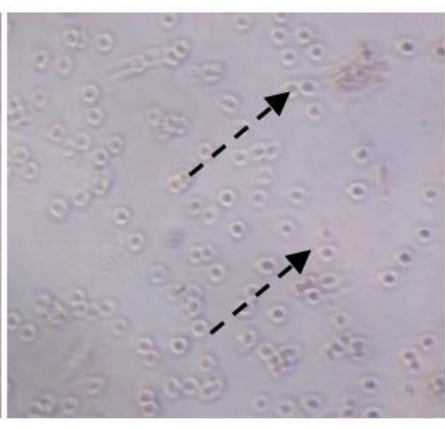

(B)

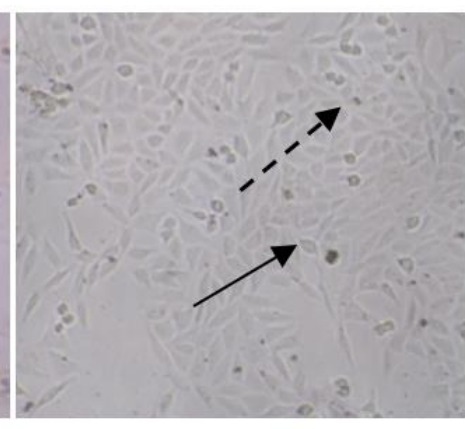

(C)

Figure 2. The morphology of T47D cell after incubation for 24. Control of T47D cell (A); Doxorubicin $250 \mathrm{nM}(\mathrm{B})$; MLE $1000 \mu \mathrm{g} / \mathrm{mL}(\mathrm{C})$. The living cells is indicated by $(\longrightarrow)$ while the dead cells is marked by $(---\rightarrow)$

Table I. Combination Index $(\mathrm{Cl})$ of MLE and Doxorubicin in T47D breast cancer cells.

\begin{tabular}{ccccc}
\hline $\begin{array}{c}\text { MLE } \\
\text { Concentration } \\
(\mu \mathrm{g} / \mathrm{mL})\end{array}$ & \multicolumn{4}{c}{ Doxorubicin concentration (nM) } \\
\cline { 2 - 5 } $\mathbf{2 5 2 . 5 0}$ & $\mathbf{7 1}$ & $\mathbf{4 7 . 0 0}$ & $\mathbf{3 5 . 2 5}$ & $\mathbf{2 3 . 5 0}$ \\
\hline 168.33 & 0.6 & 1.0 & 0.6 & 0.7 \\
126.25 & 1.1 & 1.1 & 1.0 & 0.9 \\
$\mathbf{8 4 . 1 7}$ & 1.4 & 0.8 & 1.3 & 0.6 \\
\hline
\end{tabular}


Combination Index in Table 1 shows that the combination MLE of $252.50 \mu \mathrm{g} / \mathrm{mL}$ with doxorubicin of $71 \mathrm{nM}$ and $35.25 \mathrm{nM}$; the combination MLE of $126.25 \mu \mathrm{g} / \mathrm{mL}$ and doxorubicin of $23.50 \mathrm{nM}$; and the combination MLE of $84.17 \mu \mathrm{g} / \mathrm{ml}$ and doxorubicin of 47.00 $\mathrm{nM}$ and $23.50 \mathrm{nM}$, provides a synergistic effect which means it has a greater cytotoxic effect than the sole effect of each compound. The best synergistic effect is shown by the combination MLE of $84.17 \mu \mathrm{g} / \mathrm{mL}$ and doxorubicin of 23.50 $\mathrm{nM}$ with CI value of 0.5. Doxorubicin and MLE combination effects in T47D breast cancer cells is shown in Fig. 3.

Flowcytometry analysis using FACS Calibur program is presented in Fig. 4, while the percentage of cell cycle distribution in Table 2. The result shows that the control cells undergo cell distribution in phase G1, S and G2/M. Single treatment of MLE causes an accumulation of cells in G2/M phase, while single treatment of Doxorubicin causes an accumulation of cells in G1 phase. The different mechanism of action may occur for a synergistic effect in combination MLE and Doxorubicin. Combination Index calculation results as shown in Table 1 and Fig. 3 confirmed the synergism MLE and Doxorubicin. Doxorubicin and MLE combination treatment is lowering the number of cells that accumulate in the G1 phase which was originally raised by doxorubicin, while increasing accumulation of cells in G2/M phase. It shows the influence MLE in increasing cell accumulation in G2/M phase, which means giving an inhibitory effect on G2/M phase.

The results of apoptosis induction is presented in Fig. 5, while the percentage of cell death are shown in Table 3.

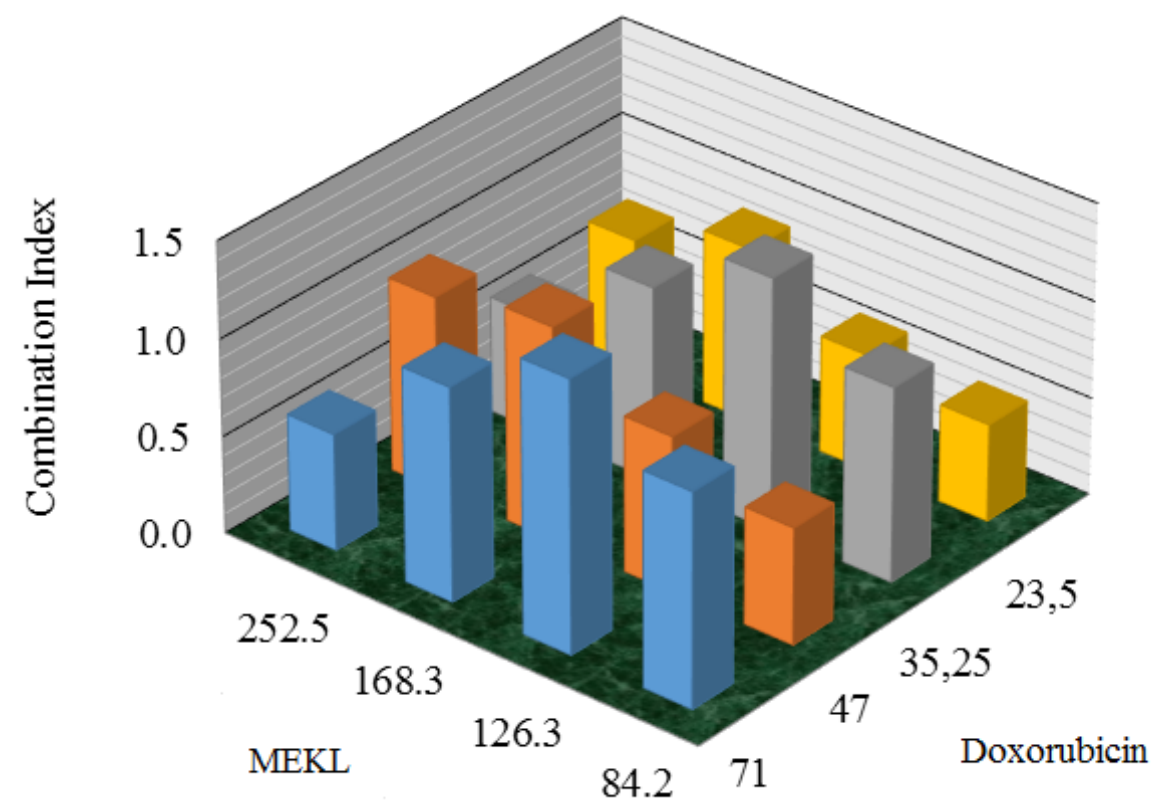

Figure 3. Combination effects of MLE and doxorubicin in T47D breast cancer cells. 


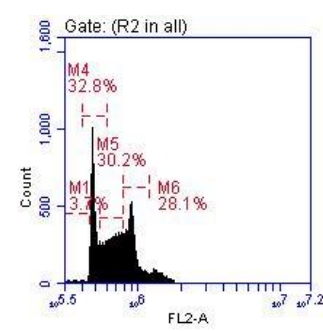

(A)

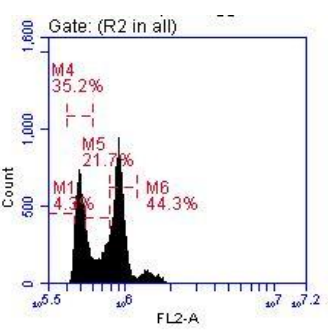

(B)

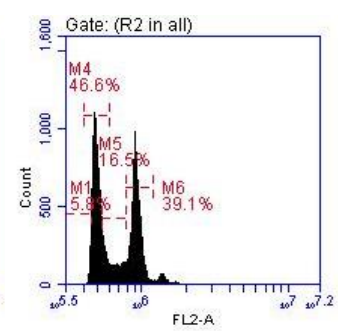

(C)

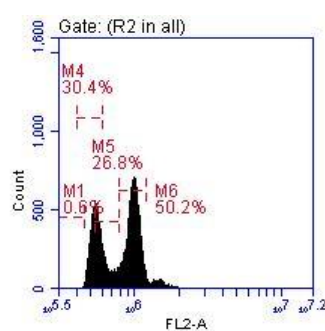

(D)

Figure 4. Analysis of T47D cell cycle distribution using flowcytometry. Cell control (A); MLE of 84.17 $\mu \mathrm{g} / \mathrm{mL}$ (B); Doxorubicin of $23.5 \mathrm{nM}$ (C); MLE of $84.17 \mu \mathrm{g} / \mathrm{mL}+$ Doxorubicin of $23.5 \mathrm{nM}$ (D).

Table 2. The distribution of T47D cells in cell cycle phases after treatment

\begin{tabular}{cccc}
\hline Sample & GI phase (\%) & S phase (\%) & G2/M phase (\%) \\
\hline Kontrol Sel & 32.78 & 30.24 & 28.08 \\
MLE 84.17 $\mu \mathrm{g} / \mathrm{mL}$ & 35.24 & 21.74 & 44.29 \\
Doxorubicin 23.5 nM & 46.57 & 16.45 & 39.10 \\
MLE 84.17 $\mu \mathrm{g} / \mathrm{mL}+$ Doxorubicin 23.5 nM & 30.37 & 26.76 & 50.20 \\
\hline
\end{tabular}

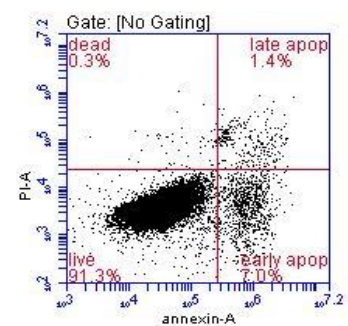

(A)

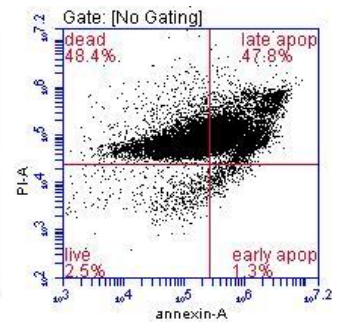

(B)

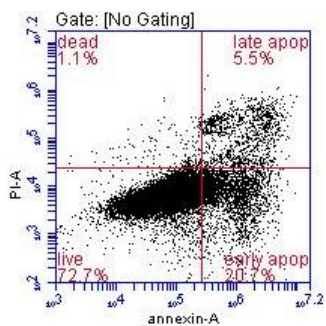

(C)

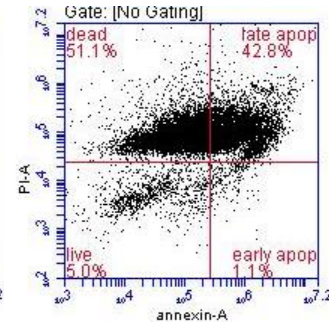

(D)

Figure 5. Analysis of T47D cell cycle distribution using flowcytometry. Cell control (A); MLE of 84.17 $\mu \mathrm{g} / \mathrm{mL}$ (B); Doxorubicin of $23.5 \mathrm{nM}$ (C); MLE of $84.17 \mu \mathrm{g} / \mathrm{mL}+$ Doxorubicin of $23.5 \mathrm{nM}$ (D).

Table 3. Death Percentage Cells after Treatment in Breast Cancer Cells T47D

\begin{tabular}{ccccc}
\hline & $\begin{array}{c}\text { Cell } \\
\text { control }\end{array}$ & $\begin{array}{c}\text { MLE 84.17 } \\
\boldsymbol{\mu g} / \mathbf{m L}\end{array}$ & $\begin{array}{c}\text { Doxorubicin } \\
\mathbf{2 3 . 5} \mathbf{~ n M}\end{array}$ & $\begin{array}{c}\text { MLE 84.17 } \mathbf{\mu g} / \mathbf{m L}+ \\
\text { Doxorubicin 23.5 nM }\end{array}$ \\
\hline Early apoptosis (\%) & 6.97 & 1.30 & 20.72 & 1.10 \\
Late apoptosis (\%) & 1.44 & 47.84 & 5.52 & 42.82 \\
Necrosis (\%) & 0.30 & 48.39 & 1.06 & 51.11 \\
Total (\%) & 8.71 & 97.53 & 27.30 & 95.03 \\
\hline
\end{tabular}


As shown in Table 3, combination of MLE and doxorubicin provides apoptosis percentage of $43.92 \%$ which is presenced the induction of apoptosis in T47D breast cancer cells. Treatment of Doxorubicin sole give the apoptosis percentage of $26.24 \%$ indicates the lower induction of apoptosis than its combination, which means that the addition MLE is able to increase the apoptotic effects of doxorubicin. The mechanism of action of doxorubicin involves its bond with DNA through intercalation between the base pairs and inhibit the synthesis of DNA and RNA through rioting template and steric hindrance. Another mechanism of action involves binding to the lipid membrane of cells that will turn various cellular functions and interacts with topoisomerase II to form the complex of DNA cutter (Rock and DeMichele, 2003). MLE contains flavonoids and quercetin glycosides (Abas, et al., 2003). Quercetin is able to induce apoptosis through the mitochondrial pathway, which disrupt MMP thereby triggering the release of cytochrome $\mathrm{c}$ into the cytoplasm and the activation of caspase- 3 and caspase-7 (Gibellini, et al., 2011).

\section{CONCLUSION}

Based on observations of modulation of cell cycle and apoptosis induction, MLE and doxorubicin combination with a concentration of $84.17 \mathrm{ug} / \mathrm{mL}-23.5 \mathrm{Nm}$ is able to inhibit cell proliferation in $\mathrm{G} 2 / \mathrm{M}$ phase and increase the induction of apoptosis of breast cancer cells T47D.

\section{ACKNOWLEDGE}

Researchers praise to Allah SWT blessing of His mercy and grace so this study can be run smoothly. Thanks to the Kemristekdikti who have funded this research, Faculty of Pharmacy, University of Wahid Hasyim Semarang, B2P2TOOT, Ms. Sari Haryanti, M.Sc., Apt., Ms. Devi Nisa H., S.Farm. M.Sc., as well as all those who have helped smooth the study.

\section{REFERENCES}

Abas F., Shaari, K., Lajis, N.H., Israf, D.A. and Kalsom, Y.U., 2003, Anti oxidative and Radical Scavenging Properties of The Constituents Isolated From Tagetes patula Jusst, Nat. Prod. Science, 9(4), 245-248.

Ayers, L., Kohler, M., Harrison, P., Sargent, I., Dragovic, R. and Schaap, M., 20II, Measurement of Circulating Cellderived Microparticles by Flowcytometry: Source of Variability within the Assay, Thromb. Res., I 27(4), 370-377.

Depkes RI, 1979, Farmakope Indonesia, 3rd Edition, Jakarta: Departemen Kesehatan Republik Indonesia.

Drummond, C., 2007, The Mechanism of Antitumour Activity of the DNA Binding Agent SN 28049, Thesis, New Zealand: University of Auckland.

Fita, F.E., Listianingsih, D., Pradana, R.G. and Safitri E.I., 2015, Kolaborasi Ekstrak Metanol Daun Kenikir dan Doksorubisin sebagai Upaya Pengembangan Agen Kokemoterapi Terhadap Sel Kanker Payudara T47D, Studi in Vitro dan in Silico, Semarang: Seminar Nasional Peluang Herbal Sebagai Alternative Medicine.

Gattenlohner, S., Etschmann, B., Kunzmann, V., Thalheimer, A., Hack, M. and Kleber, G., 2009, Concordance of KRAS/BRAF Mutation Status in Metastatic Colorectal Cancer Before and After Anti-EGFR Therapy, J. Oncol., 2009(2009), I-8.

Gibellini, L., Marcello P., Milena N., Jonas P.M., Sara, D.B., Erika, R., et al., 20II, Quercetin and Cancer Chemoprevention, Evid. Based Complementary Altern. Med., 20I I, I15.

IARC, 2013, Latest World Cancer Statistics Global Cancer Burden Rises To 14.I Million New Cases In 2012: Marked Increase In Breast Cancers Must Be Addressed, Geneva: World Health Organization.

Jemal, A., Siegel, R., Ward, E., Murray, T., Xu, J.T. and Michael J.T., 2007, Cancer Statistic 2007, CA Cancer J. Clin., 57(I), 43-66.

Mossmann, T., 1983, Rapid Colorimetric Assay for Cellular Growth and Survival, Application to Proliferation and Cytotoxicity Assays, J. Immunol. Methods, 65(I-2), 55-63.

Rock, E. and DeMichele, A., 2003, Nutritional Approaches to Late Toxicities of Adjuvant Chemotherapy 86 in Breast 
Cancer Survivors, American Society for Nutritional Sciences, J. Nutr., I 33( I I Suppl I), 3785S-3793S.

Singal, P.K., lliskovic, N., Li, T. and Kaur, K., 200I, Heart Failure Due to Doxorubicin, Kuwait Medical Journal, 33(2), III-II5.
Smith, L., Watson, M.B., O’Kane, S.L.,Drew, P.J. and Lind, M.J., 2006. The Analysis of Doxorubicin Resistance in Human Breast Cancer Cell Using Antibody Microarray, Mol. Cancer Ther., 5(8), 2II5-2I 20. 